\title{
Assessment of the Impact of Atmospheric Corrosivity on the Cement Concrete Airfield Pavement's Operation Process
}

\author{
Mariusz Wesolowski $\odot$, Aleksandra Rumak * ${ }^{\circ}$, Pawel Iwanowski $@$ and Adam Poswiata \\ Air Force Institute of Technology, Airfield Pavement Division, 601-494 Warsaw, Poland; \\ mariusz.wesolowski@itwl.pl (M.W.); pawel.iwanowski@itwl.pl (P.I.); adam.poswiata@itwl.pl (A.P.) \\ * Correspondence: aleksandra.rumak@itwl.pl; Tel.: +48-261-851-424
}

Received: 9 October 2020; Accepted: 30 October 2020; Published: 17 November 2020

\begin{abstract}
The aim of this research is to assess corrosion in natural atmospheric conditions, based on exposure of material samples and periodic monitoring, and to determine the size of corrosion losses, their form and appearance, as well as changes in physical properties at regular time intervals. Atmospheric corrosion tests were ultimately carried out in order to determine the corrosion resistance of a cement concrete airfield pavement, as well as to assess the type of corrosion and research data in order to determine and estimate the corrosivity of the atmosphere. Atmospheric corrosivity is one of the parameters characterizing the technical condition of airfield pavement functional elements; it makes it possible to estimate a suitable frequency of airfield periodic inspections. Assessments of concrete corrosion and atmospheric corrosivity enable appropriate countermeasures to be taken in order to maintain the airport functional elements in a constant state of technical readiness. In the following study, the prepared samples were exposed to atmospheric conditions in designated places located at selected military airport facilities. Corrosion samples in the form of $50 \mathrm{~mm} \times 100 \mathrm{~mm}$ standard samples, $1 \mathrm{~mm}$ to $3 \mathrm{~mm}$ in thickness, were placed on special frames located within fenced corrosion stations. The corrosion rate $r_{\text {corr }}$ of a specific metal, expressed as a corrosion loss, depends on the environmental conditions. This article presents an atmosphere corrosivity category assessment for low-carbon steel, zinc, copper and aluminum reference samples, taking into account weight or thickness loss after one year of exposure.
\end{abstract}

Keywords: atmosphere; corrosion; corrosion station; cement concrete pavement; corrosion rate

\section{Introduction}

Atmosphere corrosivity is one of the parameters characterizing the airfield pavement's technical condition of the airport functional elements. Concrete corrosion phenomena are related to processes in aircraft construction. Research in this field is based on analyses of the influence of atmospheric conditions on the technical conditions of airfield pavements [1]. A condition analysis in which the surfaces of an airport's functional elements (EFL) are examined should be carried out taking into account the adverse influence of the atmospheric environment in which the pavement is used. Atmospheric environments differ in terms of insolation, temperature, humidity and the presence of pollutants [2]. Aircraft constructions with specific corrosion resistance in one respect may not be resistant in another.

Having the test results for the defined period and knowing the correlations with the parameters characterizing the atmospheric conditions, it is possible to limit the collection of environmental data, so that their impact can be determined on the basis of the corrosion losses of reference samples [3]. It is possible to develop a mathematical model for forecasting atmosphere corrosivity with established 
relationships between laboratory test results (accelerated tests) and natural (field tests within the relevant airport) conditions. Scientists from China [4,5] have presented their approach for assessing corrosion rates, both in laboratory and field corrosion tests.

Assessments of atmospheric corrosion are extremely complicated due to environmental parameters, concentrations of anthropogenic and natural pollutants, and constantly changing climate parameters, such as temperature, pressure, insolation, humidity and many others. The impact of the natural environment, as well as concentrations of air pollution, on the corrosion process is highlighted in $[6,7]$. According to these sources, nowadays, we are facing a so-called "multipollutant atmospheric environment" that directly affects corrosion processes.

The main purpose of this work is to present atmosphere corrosivity category assessments of low-carbon steel, zinc, copper and aluminum reference samples, including weight or thickness losses, after one year of exposure. The results of weight and thickness losses included all analyzed metal alloys excluding aluminum, as aluminum alloys, in conditions of atmospheric corrosion, preserve relatively high corrosion resistance due to the formation of an oxide coating on their surface which protects them from further oxidation [8]. The authors of [9-11] present atmospheric corrosion test results of metals including aluminum, copper, carbon steel, galvanized steel and zinc on the basis of reference samples tests, while further aluminum corrosion and product assessments were comprehensively presented by [12-14]. An attempt to model atmosphere corrosivity was made using mechanistic models and experiments in [15]. Finally, statistical indicators of the reliability of predicting the corrosion losses of metals were calculated for various categories of atmosphere corrosivity in [16].

Currently used methods of the technical pavement condition assessments mostly rely on visual assessments of pavement deterioration. The authors of the present research propose a method based on the impact of atmosphere corrosivity on cement concrete pavements. In the following sections, the authors will present test results, and will discuss the possibility of including the vulnerability of pavements to corrosion deterioration and atmosphere corrosivity in a model characterizing the pavement usage process, in order to assess the technical conditions thereof. Lastly, the authors will discuss results and present the conclusions of the paper.

\section{Materials and Methods}

Atmospheric corrosion is the most common material deterioration process [17]. Taking into account the atmosphere type and the process mechanism, corrosion can be categorized as: dry atmosphere corrosion (i.e., where chemical corrosion takes place), humid atmosphere corrosion (i.e., where electrochemical corrosion with oxygen depolarization occurs), or wet atmosphere corrosion (in which water vapor condenses on the surface of the material, creating a water film [18]). The climate and, above all, the microclimate conditions (e.g., sea microclimate, forested area microclimate) have a direct impact on the atmosphere. Anthropogenic activity also introduces pollutants into the atmosphere in the form of dust and gases, which increase electrolyte concentrations and aggressiveness towards metal surfaces $[19,20]$.

The nondestructive methods of recognizing corrosion signs are widely discussed in the literature. In the construction of roads and airport pavements, these methods are used primarily to detect signs of reinforcing steel corrosion. One of the modern approaches is the GPR (ground-penetrating radar) method to diagnose the effects of corrosion in reinforced structures [21]. Different levels of corrosion of reinforcing steel lead to the detection of different signals from the GPR. The authors of [22] presented an assessment of the corrosion of reinforcing steel using GPR in combination with infrared thermography (IRT). The combination of these two methods allowed for an even more accurate analysis of reinforced concrete in the context of the reinforcing steel corrosion. While nondestructive techniques of corrosion detection are gaining popularity $[23,24]$, the atmosphere corrosivity parameter may be one of the elements on the basis of which it is possible to determine the degree of pavement deterioration, not only according to the level of corrosion of reinforcing steel, but also considering the corrosion of cement concrete in specific corrosive atmospheric conditions. This will make it possible to estimate the duration 
of safe operation of a specific airport functional element (after which it would be advisable to carry out renovations), thus allowing the transition to the use of airport functional elements in accordance with its technical condition, thus keeping them in constant technical readiness [25].

Corrosion in natural atmospheric conditions on the basis of exposure of samples, periodic observations and determination of the corrosion losses, their form and appearance, as well as changes in physical properties at regular time intervals, is being assessed [26,27].

Permanent corrosion stations, where reference samples are exposed, are located in selected military airport facilities, i.e., in Lask, Minsk Mazowiecki, Malbork, Krakow, Powidz, Swidwin, Miroslawiec, Poznan-Krzesiny, Gdynia, Darlowo and Radom. Corrosion stations are fenced places with metal frames on which corrosion samples are located. The frames are attached to concrete floor. The vegetation in the immediate vicinity of the frame was removed or mowed. The reference samples are attached with grips to the frame.

There are no objects nearby the frames that would reflect solar radiation. Figures 1 and 2 present an example of a corrosion station placed at one of the airport facilities.

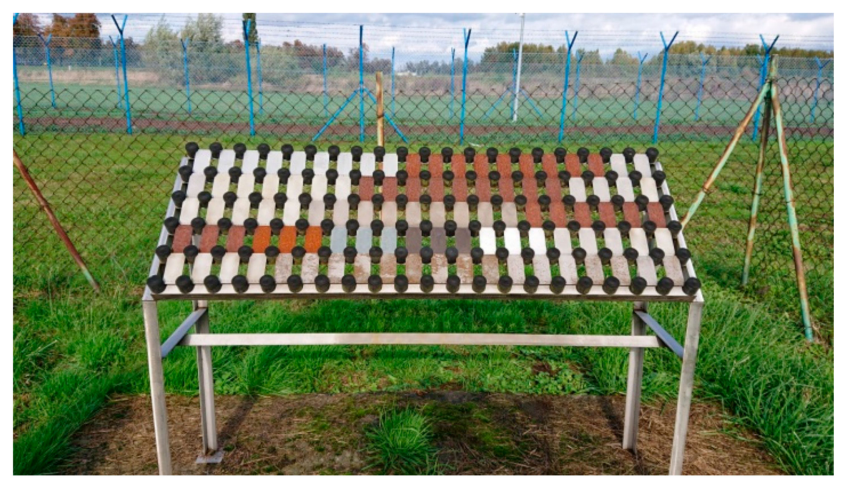

Figure 1. Corrosion station including low-carbon steel, zinc, copper and aluminum standard samples located at one of the polish military airport facilities.

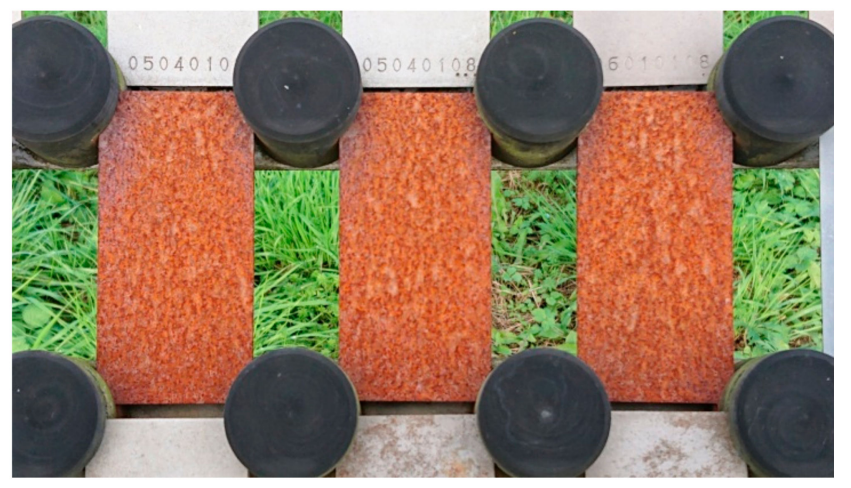

Figure 2. Low-carbon steel standard samples after 1 year of atmospheric exposure.

Standard samples (reference samples) are of $50 \mathrm{~mm} \times 100 \mathrm{~mm}$ dimensions and $1 \mathrm{~mm}$ to $3 \mathrm{~mm}$ in thickness. The plates were not protected with any anti-corrosion agent. They were properly marked by stamping sequence of characters on the front (tested) side of the sample. Atmospheric corrosion tests were carried out from October 2016 to November 2017. Data were obtained from permanent corrosion stations listed in this chapter. The samples were prepared according to the EN ISO 8565: 2012 [3] standard. Before the sample exposure, all samples were cleaned with an organic solvent or alkaline degreasing liquids. Old samples at corrosion stations were replaced with new ones.

The samples were weighed and measured after they were brought to the laboratory of Airfield Division. Then, corrosion products were removed in accordance with EN ISO 8407 [28]. Samples were weighed and measured once again. Samples were weighed with an analytical balance; the thickness 
measurement at five points was made with a digital micrometer. The corrosion rate was calculated with Formula (1), according to EN ISO 9226 [29]. The atmosphere in the area of the analyzed objects was classified in terms of the atmosphere corrosivity category according to EN ISO 9223: 2015 [28].

$$
r_{\mathrm{corr}}=\frac{\Delta m}{A \times t}
$$

where:

$r_{\text {corr }}$-corrosion rate;

$\Delta m$-mass loss (g);

$A$-sample surface area, $\left(\mathrm{m}^{2}\right)$;

$t$-exposure time of the corrosive sample, (years).

\section{Results}

Figure 3 presents the ranking of corrosion stations with the highest thickness losses of standard samples. Further, Figure 4 presents the ranking of corrosion stations with the highest weight losses of standard samples. Numbering 1 to 11 applies, where 1 is the corrosion station with the highest registered losses of all analyzed metal alloys, excluding aluminum.

\begin{tabular}{|c|c|c|c|c|c|c|c|}
\hline & Low-carbon steel & Zinc & Copper & Aluminum & Rank & Rank - Al & $\mathbf{R}$ \\
\hline Radom & 2 & 4 & 2 & 6 & 14 & 8 & 11 \\
\hline Krakow & 8 & 6 & 1 & 8 & 23 & 15 & 8 \\
\hline Miroslawiec & 11 & 3 & 8 & 1 & 23 & 22 & 2 \\
\hline Swidwin & 10 & 7 & 3 & 2 & 22 & 20 & 5 \\
\hline Malbork & 6 & 11 & 9 & 9 & 35 & 26 & 1 \\
\hline Minsk Mazowiecki & 7 & 1 & 7 & 4 & 19 & 15 & 8 \\
\hline Poznan-Krzesiny & 4 & 8 & 6 & 7 & 25 & 18 & 6 \\
\hline Lask & 9 & 2 & 10 & 3 & 24 & 21 & 3 \\
\hline Powidz & 3 & 10 & 5 & 5 & 23 & 18 & 6 \\
\hline Gdynia & 5 & 5 & 11 & 11 & 32 & 21 & 3 \\
\hline Darlowo & 1 & 9 & 4 & 10 & 24 & 14 & 10 \\
\hline
\end{tabular}

Figure 3. The ranking of corrosion stations with the highest thickness losses of standard samples. 


\begin{tabular}{|c|c|c|c|c|c|c|c|}
\hline & \begin{tabular}{|l|} 
Low-carbon steel \\
\end{tabular} & Zinc & Copper & Aluminum & Rank & Rank-AI & $\mathbf{R}$ \\
\hline Radom & 5 & 3 & 11 & 11 & 30 & 19 & 7 \\
\hline Krakow & 1 & 8 & 2 & 8 & 19 & 11 & 1 \\
\hline Miroslawiec & 9 & 5 & 1 & 3 & 18 & 15 & 4 \\
\hline Swidwin & 11 & 7 & 8 & 1 & 27 & 26 & 11 \\
\hline Malbork & 8 & 9 & 7 & 6 & 30 & 24 & 9 \\
\hline Minsk Mazowiecki & 10 & 6 & 3 & 2 & 21 & 19 & 7 \\
\hline Poznan-Krzesiny & 6 & 2 & 9 & 10 & 27 & 17 & 5 \\
\hline Lask & 4 & 4 & 4 & 9 & 21 & 12 & 2 \\
\hline Powidz & 7 & 1 & 6 & 5 & 19 & 14 & 3 \\
\hline Gdynia & 3 & 11 & 10 & 7 & 31 & 24 & 9 \\
\hline Darlowo & 2 & 10 & 5 & 4 & 21 & 17 & 5 \\
\hline
\end{tabular}

Figure 4. The ranking of corrosion stations with the highest weight losses of standard samples.

Figures 5-8 present the correlation between weight and thickness losses for different metal alloys. Table 1 also presents the r-Pearson coefficients, $\mathrm{r}^{2}$ and the probability $p$. The significant correlation coefficients for which the probability of the first type error was less than the assumed $\alpha=0.05$ are marked red. It corresponded to the confidence interval of $95 \%$.

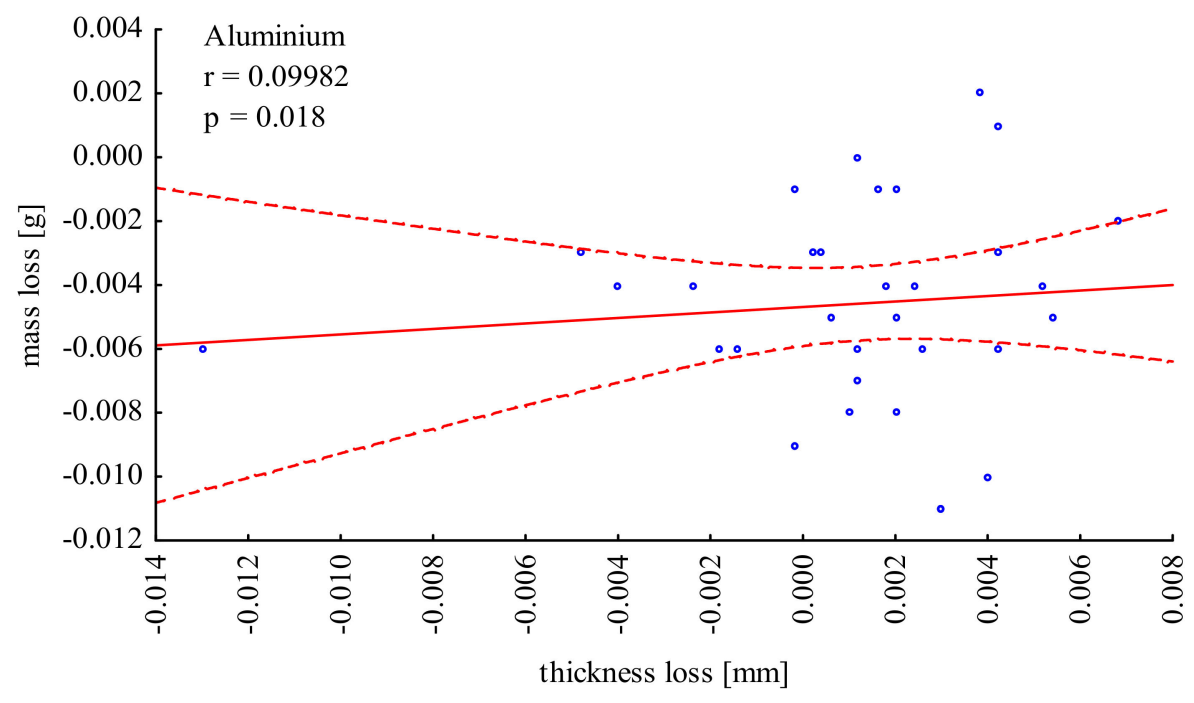

Figure 5. Correlation of weight and thickness losses for aluminum alloy. 


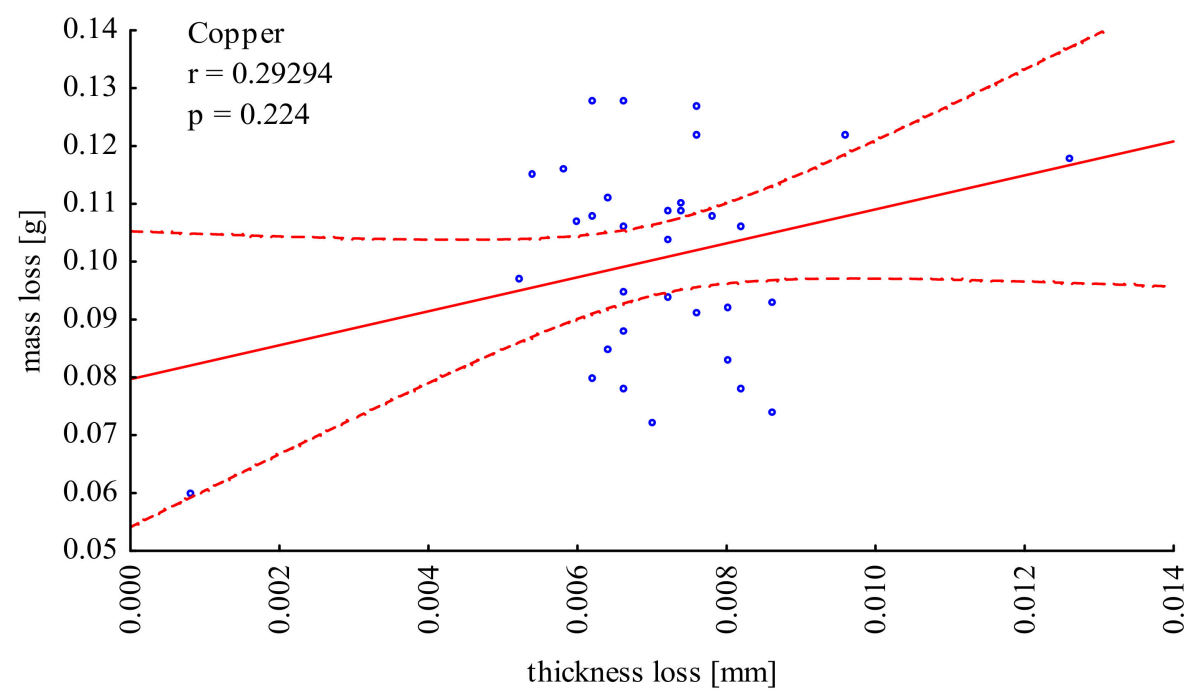

Figure 6. Correlation of weight and thickness losses for copper alloy.

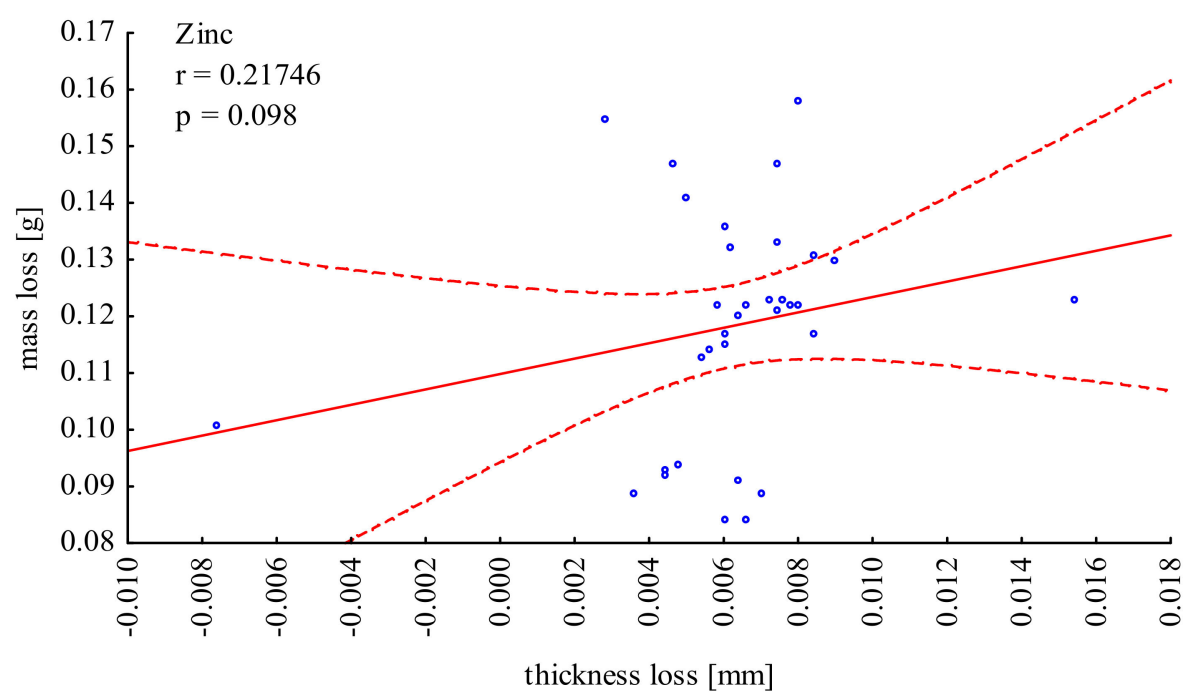

Figure 7. Correlation of weight and thickness losses for zinc alloy.

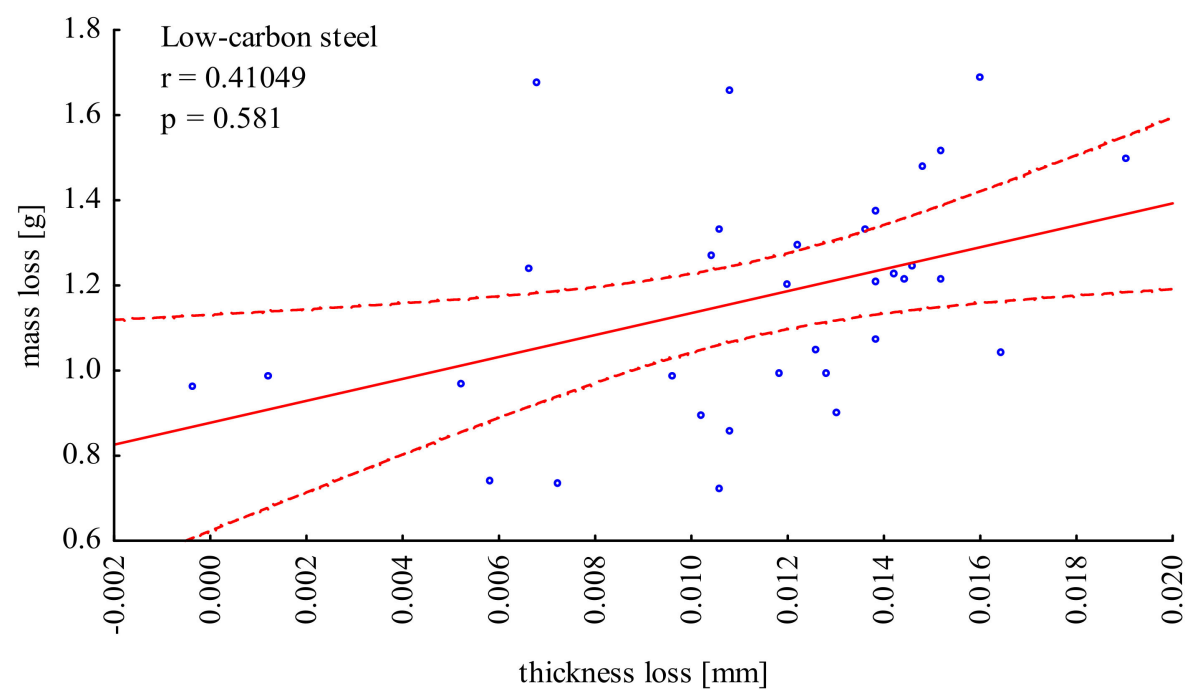

Figure 8. Correlation of weight and thickness losses for low-carbon steel alloy. 
Table 1. The results of the statistical analysis of the correlation between the weight loss and the thickness of the samples.

\begin{tabular}{lccc}
\hline \multicolumn{1}{c}{ Metal Alloy } & R-Pearson Coefficient & $\boldsymbol{r}^{2}$ & $\boldsymbol{p}$ \\
\hline Aluminum & 0.41 & 0.010 & 0.018 \\
\hline Copper & 0.22 & 0.086 & 0.224 \\
\hline Zinc & 0.29 & 0.047 & 0.098 \\
\hline Low-carbon steel & 0.10 & 0.169 & 0.581 \\
\hline
\end{tabular}

Considering the above, the satisfactory value of Pearson's $r$ index was not obtained in any of the cases. It was assumed as 0.8 for purposes of the analysis with the assumed confidence interval of $95 \%$. The highest value of $r$-Pearson coefficient was obtained for steel ( $r=0.41$ ); however, it was still much lower than the assumed. In conclusion, there is no clear correlation between the results of thickness and weight losses of the reference samples.

Table 2 presents the corrosivity categories determined on the basis of corrosion rates $\left(r_{\text {corr }}\right)$ of low-carbon steel, zinc, copper and aluminum reference samples, after the first year of exposure according to EN ISO 9223: 2015.

Table 2. Corrosion rates $r_{\text {corr }}$ after first year of exposure for each corrosivity category.

\begin{tabular}{cccccc}
\hline \multirow{2}{*}{ Corrosivity Category } & \multicolumn{5}{c}{ Corrosion Rates } \\
& \multicolumn{5}{c}{$r_{\text {corr }}$} \\
\cline { 2 - 6 } & Unit & Low-Carbon Steel & Zinc & Copper & Aluminum \\
\hline \multirow{2}{*}{ C1 } & $\mathrm{g} /\left(\mathrm{m}^{2} \times \mathrm{a}\right)$ & $r_{\text {corr }} \leq 10$ & $r_{\text {corr }} \leq 0.7$ & $r_{\text {corr }} \leq 0.9$ & not relevant \\
\cline { 2 - 6 } & $\mu \mathrm{m} / \mathrm{a}$ & $r_{\text {corr }} \leq 1.3$ & $r_{\text {corr }} \leq 0.1$ & $r_{\text {corr }} \leq 0.1$ & - \\
\hline \multirow{2}{*}{$\mathrm{C} 2$} & $\mathrm{~g} /\left(\mathrm{m}^{2} \times \mathrm{a}\right)$ & $10<r_{\text {corr }} \leq 200$ & $0.7<r_{\text {corr }} \leq 5$ & $0.9<r_{\text {corr }} \leq 5$ & $r_{\text {corr }} \leq 0.6$ \\
\cline { 2 - 6 } & $\mu \mathrm{m} / \mathrm{a}$ & $1.3<r_{\text {corr }} \leq 25$ & $0.1<r_{\text {corr }} \leq 0.7$ & $0.1<r_{\text {corr }} \leq 0.6$ & - \\
\hline \multirow{2}{*}{$\mathrm{C} 3$} & $\mathrm{~g} /\left(\mathrm{m}^{2} \times \mathrm{a}\right)$ & $200<r_{\text {corr }} \leq 400$ & $5<r_{\text {corr }} \leq 15$ & $5<r_{\text {corr }} \leq 12$ & $0.6<r_{\text {corr }} \leq 2$ \\
\hline & $\mu \mathrm{m} / \mathrm{a}$ & $25<r_{\text {corr }} \leq 50$ & $0.7<r_{\text {corr }} \leq 2.1$ & $0.6<r_{\text {corr }} \leq 1.3$ & - \\
\hline \multirow{2}{*}{$\mathrm{C} 4$} & $\mathrm{~g} /\left(\mathrm{m}^{2} \times \mathrm{a}\right)$ & $400<r_{\text {corr }} \leq 650$ & $15<r_{\text {corr }} \leq 30$ & $12<r_{\text {corr }} \leq 25$ & $2<r_{\text {corr }} \leq 5$ \\
\cline { 2 - 6 } & $\mu \mathrm{m} / \mathrm{a}$ & $50<r_{\text {corr }} \leq 80$ & $2.1<r_{\text {corr }} \leq 4.2$ & $1.3<r_{\text {corr }} \leq 2.8$ & - \\
\hline \multirow{2}{*}{$\mathrm{C} 5$} & $\mathrm{~g} /\left(\mathrm{m}^{2} \times \mathrm{a}\right)$ & $650<r_{\text {corr }} \leq 1500$ & $30<r_{\text {corr }} \leq 60$ & $25<r_{\text {corr }} \leq 50$ & $5<r_{\text {corr }} \leq 10$ \\
\cline { 2 - 6 } & $\mu \mathrm{m} / \mathrm{a}$ & $80<r_{\text {corr }} \leq 200$ & $4.2<r_{\text {corr }} \leq 8.4$ & $2.8<r_{\text {corr }} \leq 5,6$ & - \\
\hline \multirow{2}{*}{$\mathrm{CX}$} & $\mathrm{g} /\left(\mathrm{m}^{2} \times \mathrm{a}\right)$ & $1500<r_{\text {corr }} \leq 5500$ & $60<r_{\text {corr }} \leq 180$ & $50<r_{\text {corr }} \leq 90$ & $r_{\text {corr }}>0.6$ \\
\cline { 2 - 6 } & $\mu \mathrm{m} / \mathrm{a}$ & $200<r_{\text {corr }} \leq 700$ & $8.4<r_{\text {corr }} \leq 25$ & $5.6<r_{\text {corr }} \leq 10$ & - \\
\hline
\end{tabular}

Table 3 lists the corrosivity categories for the analyzed corrosion stations, determined on the basis of the corrosion rate $r_{\text {corr }}\left(\mathrm{g} / \mathrm{m}^{2}\right)$ measurements.

Based on the research results, the least favorable conditions in terms of atmospheric corrosivity are at corrosion stations located in Krakow, Miroslawiec and Powidz. The Krakow location characterizes the highest corrosion rate $\left(\mathrm{r}_{\mathrm{corr}}=167.5\right)$ of low-carbon steel, whereas the highest copper corrosion rate $\left(\mathrm{r}_{\text {corr }}=12.8\right)$ was reported at the Miroslawiec station. The highest corrosion rate $\left(\mathrm{r}_{\text {corr }}=15.3\right)$ of zinc alloy was reported at Powidz station. Overall, the atmosphere corrosivity category in all three locations was defined at the C4 level. On the other hand, the lowest corrosion rates were reported at Malbork, Poznan-Krzesiny and Gdynia stations with the atmosphere corrosivity category determined at the C3 level.

The variation of corrosion rate results may be caused by various atmospheric conditions, as well as pollution of local low emissions (pollutant emission from households with high emission from coal heating installations), in relationship with variable conditions of pollutant dispersion and, especially in 
the case of Krakow station, the presence of agglomeration traffic pollutants. Commonly available pollutant emissions data are insufficient for the purposes of the research due to their local nature.

Table 3. Categories of the atmosphere corrosivity.

\begin{tabular}{|c|c|c|c|c|c|c|c|c|c|}
\hline \multirow[b]{2}{*}{ Corrosion Station } & \multicolumn{2}{|c|}{ Low-Carbon Steel } & \multicolumn{2}{|c|}{ Zinc } & \multicolumn{2}{|c|}{ Copper } & \multicolumn{2}{|c|}{ Aluminum } & \multirow{2}{*}{$\begin{array}{c}\text { Atmosphere } \\
\text { Corrosivity } \\
\text { Category }\end{array}$} \\
\hline & $\begin{array}{l}r_{\text {corr }} \\
\mathrm{g} / \mathrm{m}^{2}\end{array}$ & $\begin{array}{c}\text { Corrosivity } \\
\text { Category }\end{array}$ & $\begin{array}{l}r_{\text {corr }} \\
\mathrm{g} / \mathrm{m}^{2}\end{array}$ & $\begin{array}{c}\text { Corrosivity } \\
\text { Category }\end{array}$ & $\begin{array}{l}r_{\text {corr }} \\
\mathrm{g} / \mathrm{m}^{2}\end{array}$ & $\begin{array}{c}\text { Corrosivity } \\
\text { Category }\end{array}$ & $\begin{array}{l}r_{\text {corr }} \\
\mathrm{g} / \mathrm{m}^{2}\end{array}$ & $\begin{array}{c}\text { Corrosivity } \\
\text { Category }\end{array}$ & \\
\hline Radom & 123 & $\mathrm{C} 2$ & 12.8 & $\mathrm{C} 3$ & 7.5 & $\mathrm{C} 3$ & 0.0 & $\mathrm{C} 1$ & $\mathrm{C} 3$ \\
\hline Krakow & 167.5 & $\mathrm{C} 2$ & 12.0 & $\mathrm{C} 3$ & 12.1 & $\mathrm{C} 4$ & 0.4 & $\mathrm{C} 2$ & $\mathrm{C} 4$ \\
\hline Miroslawiec & 97.3 & $\mathrm{C} 2$ & 12.3 & $\mathrm{C} 3$ & 12.8 & $\mathrm{C} 4$ & 0.8 & $\mathrm{C} 3$ & $\mathrm{C} 4$ \\
\hline Swidwin & 73.3 & $\mathrm{C} 2$ & 12.1 & $\mathrm{C} 3$ & 9.3 & $\mathrm{C} 3$ & 1.1 & $\mathrm{C} 3$ & C3 \\
\hline Malbork & 99.5 & $\mathrm{C} 2$ & 9.4 & $\mathrm{C} 3$ & 9.3 & $\mathrm{C} 3$ & 0.5 & $\mathrm{C} 2$ & $\mathrm{C} 3$ \\
\hline Minsk Maz. & 88.5 & $\mathrm{C} 2$ & 12.2 & $\mathrm{C} 3$ & 11.1 & $\mathrm{C} 3$ & 0.9 & $\mathrm{C} 3$ & $\mathrm{C} 3$ \\
\hline Poznan-Krzesiny & 120.8 & $\mathrm{C} 2$ & 13.6 & $\mathrm{C} 3$ & 8.3 & $\mathrm{C} 3$ & 0.1 & $\mathrm{C} 2$ & C3 \\
\hline Lask & 127 & $\mathrm{C} 2$ & 12.5 & $\mathrm{C} 3$ & 11.1 & $\mathrm{C} 3$ & 0.4 & $\mathrm{C} 2$ & $\mathrm{C} 3$ \\
\hline Powidz & 105.4 & $\mathrm{C} 2$ & 15.3 & $\mathrm{C} 4$ & 10.6 & $\mathrm{C} 3$ & 0.6 & $\mathrm{C} 2$ & $\mathrm{C} 4$ \\
\hline Gdynia & 134.7 & $\mathrm{C} 2$ & 8.6 & $\mathrm{C} 3$ & 7.7 & $\mathrm{C} 3$ & 0.5 & $\mathrm{C} 2$ & C3 \\
\hline Darlowo & 149.8 & $\mathrm{C} 2$ & 9.3 & $\mathrm{C} 3$ & 10.8 & $\mathrm{C} 3$ & 0.7 & $\mathrm{C} 3$ & $\mathrm{C} 3$ \\
\hline
\end{tabular}

\section{Discussion}

During the usage process, airfield pavements are constantly degraded. Degradation is a process in which properties of the pavement structure are reduced due to influence of external factors, causing changes in pavement's structure. It is a process that is slow and spread over a period of time.

The basic external factors affecting cement concrete airfield pavement include, among others, atmospheric and climatic conditions and the influence of chemicals. These chemicals can come from various sources, including winter airfield maintenance (de-icing agents) or leak of hazardous substances from vehicles or aircraft moving on the pavement. Signs of premature deterioration of airfield pavement surface (for instance a characteristic pattern of cracks) due to use of de-icing agents (based on sodium acetate, potassium acetate, sodium formate and potassium formate which are commonly used in Poland) are observed [30].

It may result in the formation of point, linear and area pavement deteriorations. According to the adopted nomenclature, point deteriorations include marl spalls, fractures/chipping of edges and corners, deep cavities and boreholes. Linear deteriorations consist of slotted and wide slotted cracks, loss or excess of joint sealant mass and thresholds. Area deteriorations include shallow and deep flaking, capillaries cracks, frost cracks and slabs for replacement. Any types of surface repairs, including area, point repairs, as well as filling cracks, are also classified as deteriorations. Examples of pavement deteriorations are shown in Figure 9 below.

The current pavement condition can be determined by its degradation degree [31,32]. The degree of degradation is marked with symbol $\mathrm{D}$ and is given as a percentage, where $0 \%$ means the pavement is in perfect condition, while $100 \%$ means the pavement is completely degraded. The degree of degradation is calculated according to Formula (2).

$$
\begin{gathered}
D_{B C}^{M F}=w_{B C}^{U} \times W_{B C}^{w U F}+w_{B C}^{N} \times W_{B C}^{w N F} \\
W_{B C}^{w U F}=\sum_{i=1}^{13} \frac{\left(w_{O b}^{U}\right)_{i} \times\left(O b_{B C}^{U}\right)_{i} \times\left(p_{B C}^{U}\right)_{i}}{F} \times 100 / \sum_{i=1}^{13}\left(w_{O b}^{U}\right)_{i} \\
W_{B C}^{w c C N F}=\sum_{i=1}^{13} \frac{\left(w_{O b}^{N}\right)_{i} \times\left(O b_{B C}^{N}\right)_{i} \times\left(p_{B C}^{N}\right)_{i}}{F} \times 100 / \sum_{i=1}^{13}\left(w_{O b}^{N}\right)_{i}
\end{gathered}
$$


where:

$D^{M F}{ }_{B C}$ - degradation of cement concrete airfield pavement of an airport functional element; $p_{i}$-conversion factor of the parameter characterizing pavement surface deterioration or repair, including damaged or repaired areas;

$w_{B C}^{i}$-statistical weight of the importance of deteriorations and repairs in the evaluation of pavement degradation of an EFL;

$w^{i}$ Obi - the statistical weight of the importance of specific deteriorations and repairs in the evaluation of pavement degradation of an EFL;

$\mathrm{Ob}_{i}$ - dimensions of deteriorations and repairs of the EFL pavement;

F-total area of the tested EFL pavement;

$U$-deteriorations of the EFL pavement;

$N$-repairs of the EFL pavement.

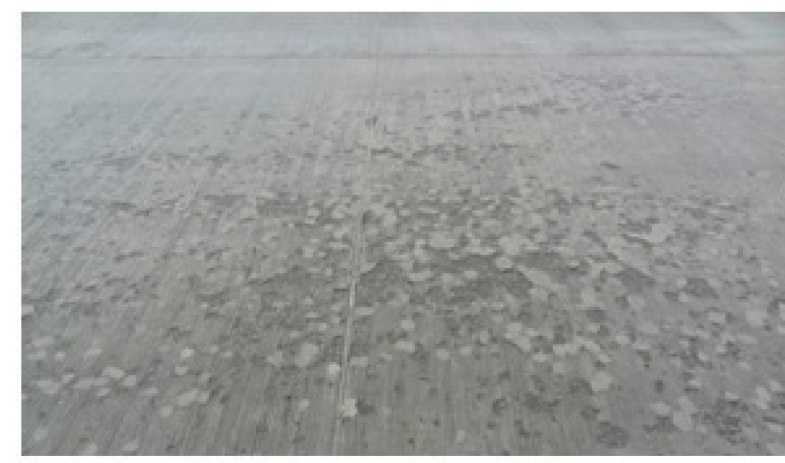

a)

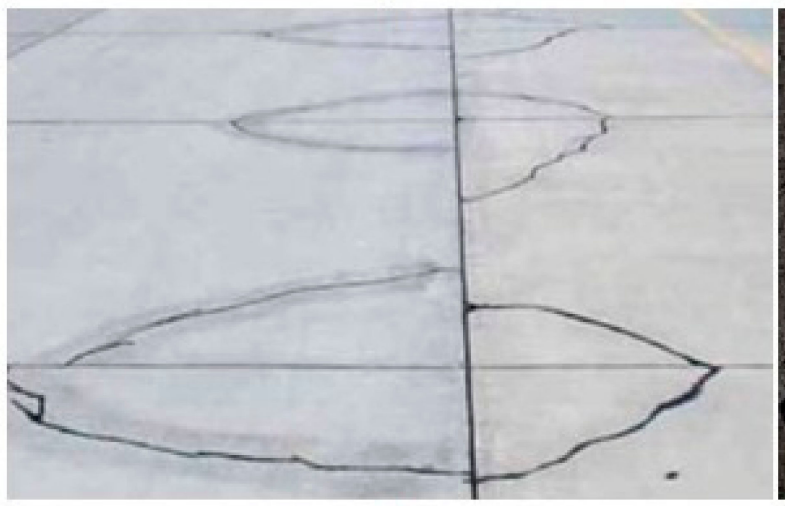

c)

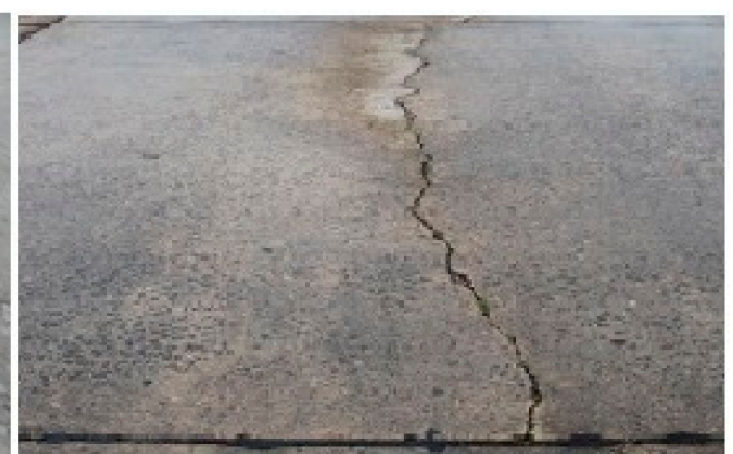

b)

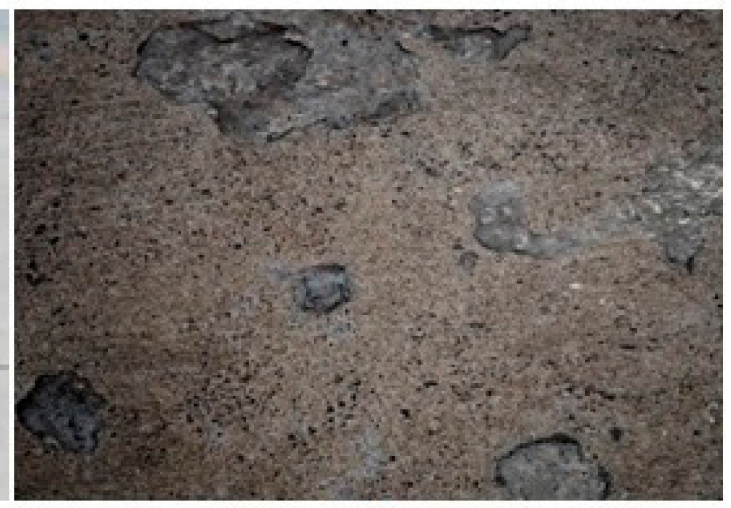

d)

Figure 9. Examples of cement concrete airfield pavement deteriorations ((a) marl spalls, (b) crack, (c) corner fractures, (d) deep flaking).

Model data are obtained due to inventory of deteriorations and repairs during periodic inspections of airfield pavements. Experts measure surface deteriorations and repairs, writing down the collected information on specially prepared forms. The data are illustrated graphically. Each damage corresponds to a predetermined symbol mapped on a functional element being evaluated. Next to the symbol, a number characterizing deterioration harmfulness is applied. The legend of measurements of cement concrete airfield pavement deteriorations and repairs (Figure 10) defines the method of applying deteriorations and repairs, which are classified to various groups, on cement concrete operational airport's functional elements, on previously prepared forms along with their measurements. Taking into account the collected data from the mathematical model (2), the assessed airport's functional element degradation degree is calculated. On the basis of the calculated degradation degree and its evaluation 
criteria, the pavement can be qualified to one of the seven classes of the standard scale or to one of the three classes of the simplified scale [33]. The criteria for the degradation degree assessment of the EFL pavement surface are presented in Figure 11.

\section{INSTRUCTIONS OF DETERIORATIONS AND REPAIRS MEASUREMENT ON} CEMENT CONCRETE AIRFIELD PAVEMENT

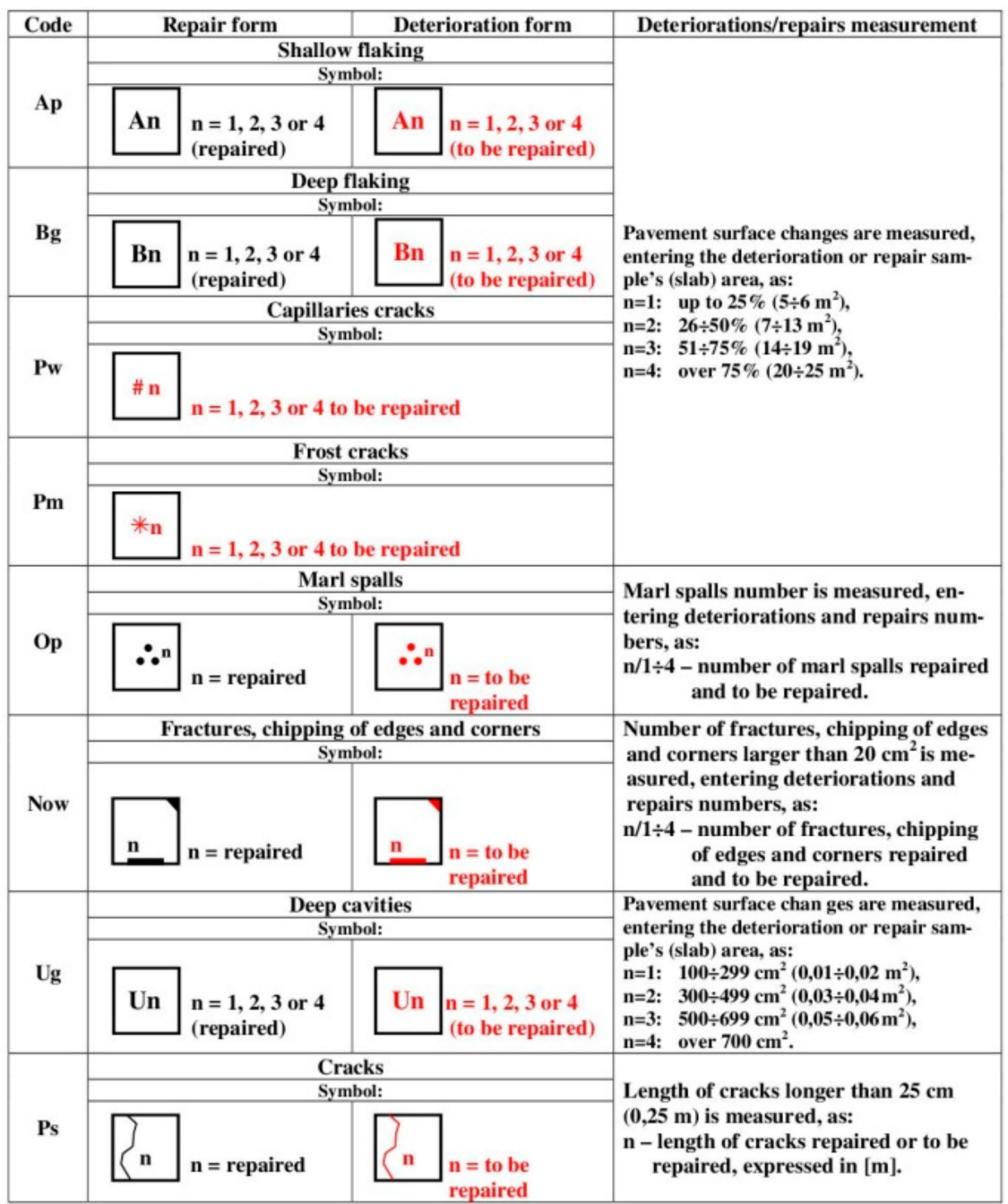

Figure 10. The legend of cement concrete airfield pavement's deteriorations and repairs measurements.

Standard scale D

Simplified scale D
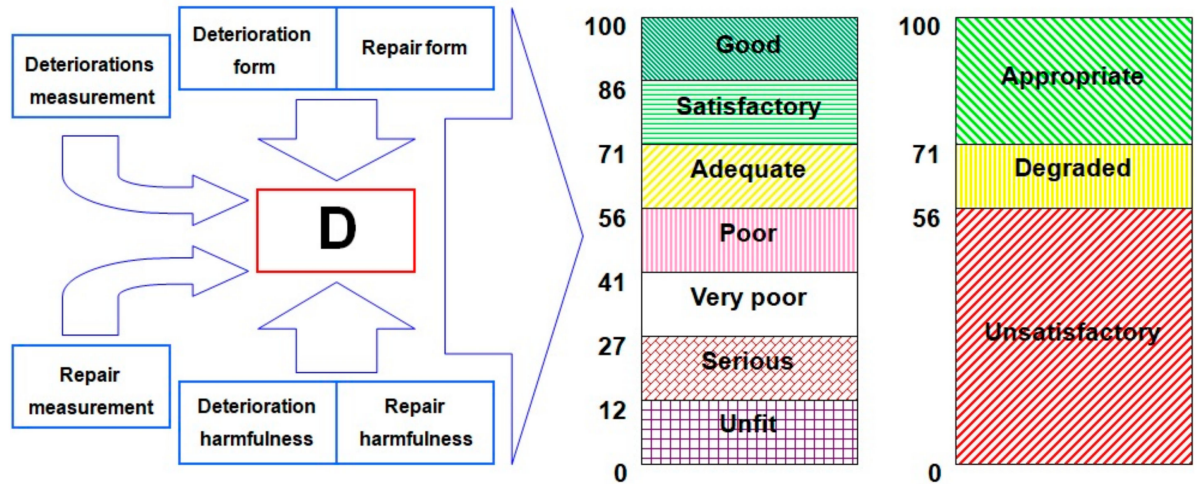

Figure 11. Criteria for the degradation degree assessment of the EFL pavement surface. 
The model characterizing the pavement usage process of airport functional elements includes, among others, the pavement exploitation vulnerability to corrosion deterioration and the atmosphere corrosivity characterizing the area of their exploitation. On the basis of the atmosphere corrosivity in relation to the airport pavement materials, the air operation's frequency, pollutants and weather conditions influence on the pavement, the frequency of airport functional elements periodic pavement inspections can be estimated. Having test results of the reference samples collected over a regular time interval and correlations with parameters characterizing atmospheric conditions, it is possible to limit the collection of environmental data, and their impact can be determined on the basis of the corrosion rates of the reference samples. Based on the collected data, it is possible to develop a mathematical model for predicting the atmosphere corrosivity, due to the established relations between the laboratory test results (accelerated tests) and test results obtained in the natural conditions prevailing in the ambient airport pavements.

\section{Conclusions}

The developed system of atmospheric corrosion assessment is designed to support the process of managing functional elements of military and civil airports by analyzing the parameters characterizing atmospheric conditions and collecting data from atmospheric corrosivity tests.

The highest category of atmospheric corrosivity was determined at the C4 level, at the corrosion stations located in Krakow, Miroslawiec and Powidz. On the other hand, the atmosphere corrosivity category at other stations was determined at the C3 level. The lowest values of corrosion rates $\left(\mathrm{g} / \mathrm{m}^{2}\right)$ were obtained at Malbork, Poznan-Krzesiny and Gdynia corrosion stations. The variation of corrosion rates results may be caused by various atmospheric conditions, as well as the pollutants emissions dispersion. Commonly available pollutant emissions data are insufficient for the purposes of the research due to their local nature. Therefore, studies of atmospheric corrosion monitoring, as well as atmospheric conditions and air quality should be continued directly at the facilities with stationary corrosion stations.

Currently, the Armed Forces of the Republic of Poland have many IT systems supporting the management of flight operations in the technical field. Data presented in the article are the basis for development of a method of estimating the durability of concrete pavement structures built in specific atmosphere corrosivity conditions. In further stages, the authors will attempt to relate the corrosion progress of the reference samples to the degradation process of airfield pavements not in relation to the reinforcing steel but to the cement concrete construction. The developed system of atmospheric corrosion assessment should support the rational management of airport pavements, for example, by collecting detailed information about the course of the pavement use process from the day of recording in the system until the end of operation, or conducting a detailed and comprehensive flight safety analysis including all airport infrastructure personnel, technical condition of the airport functional elements and supervision over measurement and research devices.

Author Contributions: M.W.: conceptualization, methodology, writing-review and editing; A.R., P.I. and A.P.: resources, formal analysis, writing-original draft and editing. All authors have read and agreed to the published version of the manuscript.

Funding: Research financed from the budget of the Ministry of Science and Higher Education as part of the statutory activity of the Airfield Division of the Air Force Institute of Technology.

Conflicts of Interest: The authors declare no conflict of interest. The funders had no role in the design of the study; in the collection, analyses, or interpretation of data; in the writing of the manuscript, or in the decision to publish the results. 


\section{References}

1. Barszcz, P. Investigations on corrosion of aircrafts in the aspect of prolonged service life and operation driven by their technical condition. Pr. Nauk. Inst. Tech. Wojsk Lotniczych 2012, 30, 59-72. [CrossRef]

2. Feliu, S.; Morcillo, M.; Chico, B. Effect of Distance from Sea on Atmospheric Corrosion Rate. Corrosion 1999, 55, 883-891. [CrossRef]

3. EN ISO 8565. Metals and Alloys-Atmospheric Corrosion Testing-General Requirements; European Committee for Standardization: Brussels, Belgium, 2012.

4. Cai, Y.; Yuanming, X.; Zhao, Y.; Xiaobing, M. Atmospheric corrosion prediction: A review. Corros. Rev. 2020, 38, 299-321. [CrossRef]

5. Wang, X.M.; Li, X.G.; Tian, X.L. Influence of temperature and relative humidity on the atmospheric corrosion of zinc in field exposures and laboratory environments by atmospheric corrosion monitor. Int. J. Electrochem. Sci. 2015, 10, 8361-8373.

6. Kobus, J.; Lutze, R. Atmospheric corrosion risk assessment. Logistyka 2015, 4, 4094-4098.

7. Kreislova, K.; Knotkova, D. The Results of 45 Years of Atmospheric Corrosion Study in the Czech Republic. Materials 2017, 10, 394. [CrossRef]

8. Bialobrzeski, A.; Czekaj, E.; Heller, M. Corrosive behavior of aluminum and magnesium alloys processed by die casting technology. Arch. Foundry 2002, 2, 294-313.

9. Mendoza, A.R.; Corvo, F. Outdoor and indoor atmospheric corrosion of carbon steel. Corros. Sci. 1999, 41, 75-86. [CrossRef]

10. Mendoza, A.R.; Corvo, F. Outdoor and indoor atmospheric corrosion of non-ferrous metals. Corros. Sci. 2000, 42, 1123-1147. [CrossRef]

11. Shiri, M.; Rezakhani, D. Estimated and Stationary Atmospheric Corrosion Rate of Carbon Steel, Galvanized Steel, Copper and Aluminum in Iran. Metall. Mater. Trans. A 2020, 51, 342-367. [CrossRef]

12. Schaller, R.F.; Jove-Colon, C.F.; Taylor, J.M.; Schindelholz, E.J. The controlling role of sodium and carbonate on the atmospheric corrosion rate of aluminum. npj Mater. Degrad. 2015, 1, 1-8. [CrossRef]

13. Sun, S.Q.; Zheng, Q.F.; Li, D.F.; Wen, J.G. Long-term atmospheric corrosion behaviour of aluminium alloys 2024 and 7075 in urban, coastal and industrial environments. Corros. Sci. 2009, 51, 719-727. [CrossRef]

14. Dan, Z.H.; Muto, I.; Hara, N. Role of corrosion products in the suppression of atmospheric corrosion of aluminum and its alloys. ECS Trans. 2010, 25, 23-33. [CrossRef]

15. Roberge, P.R.; Klassen, R.D.; Haberecht, P.W. Atmospheric corrosivity modeling-A review. Mater. Des. 2003, 23, 321-330. [CrossRef]

16. Panchenko, Y.M.; Marshakov, A.I.; Nikolaeva, L.A.; Igonin, T.N. Estimating the First-year Corrosion Losses of Structural Metals for Continental Regions of the World. Civ. Eng. J. 2020, 6, 1503-1519. [CrossRef]

17. Portellaa, M.O.G.; Portellaa, K.F.; Pereiraa, P.A.M.; Inonea, P.C.; Brambillaa, K.J.C.; Cabussúc, M.S.; Cerqueirac, D.P.; Sallesc, R.N. Atmospheric corrosion rates of copper, galvanized steel, carbon steel and aluminum in the metropolitan region of Salvador, BA, Northeast Brazil. Procedia Eng. 2012, 42, 171-185. [CrossRef]

18. Ríos-Rojas, J.F.; Aperador-Rodríguez, D.; Hernández-García, E.A.; Arroyave, C.E. Annual atmospheric corrosion rate and dose-response function for carbon steel in Bogotá. Atmósfera 2017, 30, 53-61. [CrossRef]

19. Surowska, B. Wybrane Zagadnienia z Korozji i Ochrony Przed Korozja; Politechnika Lubelska: Lublin, Poland, 2002.

20. Chico, B.; de la Fuente, D.; Díaz, I.; Simancas, J.; Morcillo, M. Annual Atmospheric Corrosion of Carbon Steel Worldwide. An Integration of ISOCORRAG, ICP/UNECE and MICAT Databases. Materials 2017, 10, 601. [CrossRef]

21. Sossa, V.; Pérez-Gracia, V.; González-Drigo, R.; A Rasol, M. Lab Non Destructive Test to Analyze the Effect of Corrosion on Ground Penetrating Radar Scans. Remote Sens. 2019, 11, 2814. [CrossRef]

22. Solla, M.; Lagüela, S.; Fernández, N.; Garrido, I. Assessing Rebar Corrosion through the Combination of Nondestructive GPR and IRT Methodologies. Remote Sens. 2019, 11, 1705. [CrossRef]

23. Kobayashi, K.; Banthia, N. Corrosion detection in reinforced concrete using induction heating and infrared thermography. J. Civil. Struct. Health Monit. 2011, 1, 25-35. [CrossRef]

24. Zhang, H.; Liao, L.; Zhao, R.; Zhou, J.; Yang, M.; Xia, R. The Non-Destructive Test of Steel Corrosion in Reinforced Concrete Bridges Using a Micro-Magnetic Sensor. Sensors 2016, 16, 1439. [CrossRef] [PubMed] 
25. Wesołowski, M.; Iwanowski, P. APCI Evaluation Method for Cement Concrete Airport Pavements in the Scope of Air Operation Safety and Air Transport Participants Life. Int. J. Environ. Res. Public Health 2020, 17, 1663. [CrossRef] [PubMed]

26. Royani, A.; Prifiharni, S.; Nuraini, L.; Priyotomo, G.; Purawiardi, I.; Gunawan, H. Corrosion of carbon steel after exposure in the river of Sukabumi, West Java. In IOP Conference Series: Materials Science and Engineering, Proceedings of the International Seminar on Metallurgy and Materials, Tangerang Selatan, Indonesia, 25-26 September 2018; IOP Publishing Ltd Bristol: Bristol, UK, 2019; Volume 541.

27. Barszcz, P. Investigation of atmospheric corrosion with use of permanent corrosion stations. Pr. Nauk. Inst. Tech. Wojsk Lotniczych 2012, 30, 5-23. [CrossRef]

28. >EN ISO 8407. Corrosion of Metals and Alloys_-Removal of Corrosion Products from Corrosion Test Specimens; European Committee for Standardization: Brussels, Belgium, 2014.

29. EN ISO 9226. Corrosion of Metals and Alloys-Corrosivity of Atmospheres-Determination of Corrosion Rate of Standard Specimens for the Evaluation of Corrosivity; European Committee for Standardization: Brussels, Belgium, 2012.

30. Shi, X. Impact of Airport Pavement Deicing Products on Aircraft and Airfield Infrastructure. A CRP Synthesis 6; Airport Cooperative Research Program, Transportation Research Board: Washington, DC, USA, 2008.

31. Wesolowski, M.; Blacha, K.; Barszcz, P. Multi-criteria analysis in assessment of the degree of degradation pavement elements functional airports made of cement concrete. In Proceedings of the Environmental Engineering 10th International Conference Materials, Vilnius, Lithuania, 27-28 April 2017; pp. 1-8.

32. Zieja, M.; Barszcz, P.; Blacha, K.; Wesolowski, M. The evaluation method of degradation degree of runway pavement surfaces constructed from cement concrete. In Safety and Reliability-Theory and Applications; Cepin, M., Bris, R., Eds.; Taylor \& Francis Group: London, UK, 2017; pp. 529-534.

33. Wesolowski, M.; Barszcz, P.; Blacha, K. Impact of airfield concrete pavements deterioration level on the safety of air operations. J. KONBiN 2018, 47, 123-142. [CrossRef]

Publisher's Note: MDPI stays neutral with regard to jurisdictional claims in published maps and institutional affiliations.

(C) 2020 by the authors. Licensee MDPI, Basel, Switzerland. This article is an open access article distributed under the terms and conditions of the Creative Commons Attribution (CC BY) license (http://creativecommons.org/licenses/by/4.0/). 